\title{
PENERAPAN EKSTRAKSI CIRI STATISTIK ORDE PERTAMA DENGAN EKUALISASI HISTOGRAM PADA KLASIFIKASI TELUR OMEGA-3
}

\author{
Febri Liantoni \\ Fakultas Teknologi Informasi, Program Studi Teknik Informatika \\ Institut Teknologi Adhi Tama Surabaya \\ Email: febri.liantoni@gmail.com \\ Agus Adi Santoso \\ Fakultas Teknologi Informasi, Program Studi Teknik Informatika \\ Institut Teknologi Adhi Tama Surabaya \\ Email: aguzady288@gmail.com
}

\begin{abstract}
ABSTRAK
Telur merupakan makanan yang memiliki gizi tinggi. Dijaman sekarang telah ada telur dengan omega3 hasil rekayasa. Secara visual untuk membedakan telur ayam biasa dan telur ayam dengan omega-3 sangat sulit karena bentuk fisik dan warna telurnya terlihat sama. Bagian yang membedakan adalah kuning telur omega-3 agak kekuningan dan kuning telur biasa lebih kemerahan. Penelitian ini diciptakan sebuah sistem analis yang mampu mengenali telur berdasarkan tekstur dengan beberapa langkah dalam teknik pengolahan citra. Beberapa teknik pengolahan citra yang digunakan yaitu konversi citra RGB ke grayscale, perbaikan kualitas citra, menghilangkan noise dengan gaussian filter dan analisis citra menggunakan ekstraksi ciri statistik orde pertama dengan nilai parameter mean, standard deviasi. Berdasarkan pengujian diperoleh tingkat precision $87,93 \%$, recall $96,22 \%$ dan accuracy $85 \%$ berdasarkan 140 data training dan 60 data uji.
\end{abstract}

Kata kunci: omega-3; ekualisasi histogram; statistik orde pertama; mean; standar deviasi.

\begin{abstract}
Eggs are foods that have high nutrition. Nowadays there are eggs that contain engineered omega-3s. Visually to distinguish between ordinary chicken eggs and chicken eggs with omega-3 is very difficult because the physical shape and color of the eggs look the same. The distinguishing part is omega-3 egg yolks rather yellowish and ordinary reddish egg yolks. This research created an analyst system that is able to recognize eggs based on texture with several steps in image processing techniques. Some image processing techniques used are the conversion of RGB images to grayscale, image quality improvement, eliminating noise with Gaussian filters and image analysis using extraction of first-order statistical features with parameter values of mean, standard deviation. Based on the test obtained the precision level is $87.93 \%$, recall $96.22 \%$ and accuracy $85 \%$ based on 140 training data and 60 test data.
\end{abstract}

Keywords: omega-3; histogram equalization; first order statistics; mean; deviation standard.

\section{PENDAHULUAN}

Telur adalah makanan bergizi tinggi yang sering digunakan dalam kehidupan. Selain memiliki kandungan protein tinggi yang lengkap, telur juga mengandung lemak [1]. Salah satu telur yang memiliki keunggulan gizi tinggi yaitu telur Omega-3. Telur Omega-3 banyak mengandung asam lemah DHA yang berguna bagi tubuh untuk meningkatkan daya tahan tubuh dan kecerdasan otak [2]. Telur omega-3 mempunyai ciri khusus yaitu warna kuning pekat karena mengandung betakaroten bisa menumbuhkan selera makan.

Berdasarkan penelitian sebelumnya dari Arivazhaga melakukan penelitian tentang identifikasi telur dengan cara mengkonversi citra RGB ke grayscale, kemudian dilakukan proses image enhancement untuk memperbaiki kualitas citra [3]. Novita ditahun 2017 menggunakan ekstraksi ciri orde pertama yang diimplementasikan pada klasifikasi batik dengan algoritma backpropagasi. Pada penelitian tersebut digunakan nilai parameter mean, skewness, kurtosis dan entropy sebagai dasar pengolahan proses klasifikasi [4]. Guan dtahun 2017 melakukan eksplorasi nilai difusi pada apparent diffusion coefficient $(A D C)$ ada ciri statistik order pertama dalam pengenalan klinis kanker serviks [5].

Secara visual telur omega-3 diketahui berdasarkan warna kuning telur. Jika dipecah telur dengan omega-3 berwarna lebih kekuningan. Berdasarkan kondisi tersebut, penelitian ini dilakukan dengan 
memanfaatkan pengolahan citra digital untuk mengetahui telur omega-3 atau telur biasa. Pengolahan citra digital merupakan pengolahan yang dilakukan kepada citra untuk mendapatkan hasil tertentu sesuai dengan kebutuhan. Cara ini dapat menjadi salah satu cara untuk menyelesaikan permasalahan mencari telur yang mengandung omega-3 maupun telur ayam biasa.

Metode untuk memperbaiki kualitas citra yaitu Ekualisasi Histogram, metode ini dilakukan dengan cara mengkonversi sebaran tingkat keabuan dari citra[6]. Cara ini bertujuan agar tingkat keabuan lebih merata pada citra. Ekualisasi histogram juga digunakan untuk meningkatkan kontras warna citra. Beberapa penelitian tentang peningkatan kontras menggunakan ekualisasi histogram dilakukan oleh Celik, Chen, dan Wang di penelitian sebelumnya. Celik melakukan perbaikan citra dengan ekualisasi histogram dua dimensi yang efektif meningkatkan kualitas dari tipe citra yang berbeda [7]. Chen mengembangkan model ekualisasi histogram untuk peningkatan kontras gambar. Pendekatannya yang dilakukan dengan model variasional yang mengandung energi fungsional untuk menyesuaikan nilai-nilai pixel dari suatu gambar masukan secara langsung sehingga histogram yang dihasilkan dapat didistribusikan kembali menjadi lebih seragam [8]. Wang juga melakukan teknik peingkatan kontrak berdasarkan algoritma ekualisasi histogram lokal. Usulan dilakukan dengan melakukan segmentasi citra menjadi beberapa sub-blok menggunakan nilai gradien, algoritma ini berhasil meningkatkan kontras lokal tanpa menambahkan derau pada citra [9].

Pada penelitian ini ekstraksi ciri statistik orde pertama digunakan untuk mengetahui kandungan omega-3 berdasarkan pengolahan citra. Ekstraksi ciri orde pertama dihitung berdasarkan nilai histogram citra. Nilai histogram ini menunjukkan probabilitas kemunculan derajat keabuan citra. Nilai mean dan standart deviasi dari ekstraksi statistik orde pertama akan digunakan untuk dasar klasifikasi telur omega-3.

\section{METODOLOGI PENELITIAN}

Pada pengolahan citra, tahapan ekstraksi fitur diperlukan untuk intepretasi citra sehingga memudahkan analisa citra pada proses klasifikasi. Ekstraksi ciri berdasarkan analisi tekstur pada umumnya membutuhkan ekstrkasi ciri pada tahap awal. Salah satu ekstrkasi ciri dapat dilakukan dengan ekstraksi ciri orde pertama. Pada penelitan ini ekstraksi ciri pertama diperoleh berdasrkan nilai ekualisasi histogram. Proses klasifikasi dilakukan untuk mengidentifikasi telur omega-3 atau telur biasa.

Beberapa tahapan penelitian meliputi input image, mengubah RGB citra ke grayscale, ekualisasi histogram, filter Gaussian, statistik orde pertama dan analisis sistem. Gambar 1 merupakan ilustrasi tahapan yang dikerjakan pada penelitian ini.

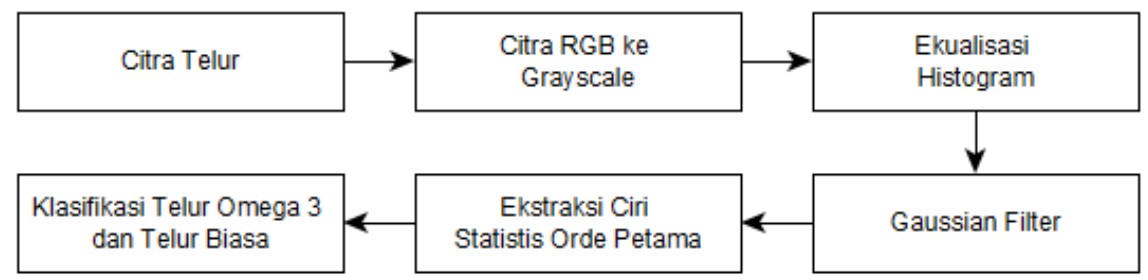

Gambar 1. Tahapan Penelitian

\subsection{Citra Telur}

Pada tahap ini dilakukan pengumpulan citra telur ayam Omega-3. Dalam penelitian ini, dataset yang digunakan berasal dari citra telur ayam dengan format JPG yang di ambil dengan kamera dengan resolusi kamera 13 MP pada ruang gelap tertutup dengan bantuan pencahayaan (lampu). Citra telur ayam yang akan digunakan berukuran 340 x 256 piksel menggunakan latar belakang berwarna putih. Proses pengambilan citra seperti pada Gambar 2.

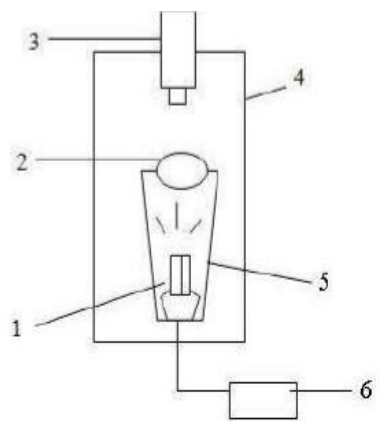

Gambar 2. Proses Pengambilan Citra 
Gambar 2 merupakan gambaran proses pengambilan citra yang dilakukan, dimana gambar 1) sumber cahaya (lampu), 2) telur ayam, 3) kamera, 4) ruang gelap tertutup, 5) tabung cahaya, 6) listrik. Hasil pengambilan citra seperti ditunjukkan pada Gambar 3.

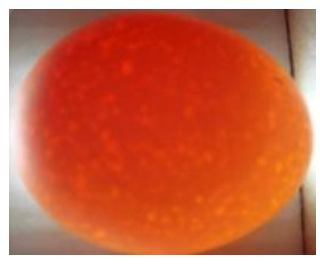

a

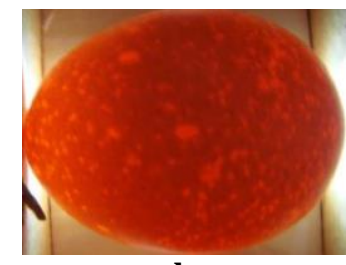

b

Gambar 3. Dataset Telur Omega-3 (a), Telur Biasa (b)

Perbedaan citra telur ditunjukkan pada warna, telur omega-3 memiliki warna keemasan, sedangkan telur biasa lebih kemerahan.

\subsection{Konversi RGB ke Grayscale}

Tahap awal yang dilakukan dalam penelitian yaitu mengubah RGB citra menjadi citra keabuan, kemudian dilakukan perbaikan dengan operasi histogram ekualisasi. Perubahan citra RGB menjadi citra keabuan dengan menggunakan metode luminosity. Proses metode luminosity dengan menghitung tiap elemen warna dari citra RGB. Penghitungan dilakukan dengan menambahkan nilai yang sesuai persepsi penglihatan manusia. Perubahan citra RGB menjadi citra keabuan dengan menggunakan Persamaan 1.

Luminosity $=\frac{R * 299+G * 587+B * 114}{1000}$

Tahapan selanjutnya adalah melakukan ekualisasi histogram pada citra telur ayam untuk memperbaiki kualitas citra dan untuk mengetahui informasi frekuensi pemakaian tingkat keabuan dalam citra telur ayam.

\subsection{Ekualisasi Histogram}

Tahap histogram ekualisasi digunakan untuk memperbaiki kualitas dari citra masukan. Informasi dari frekuensi tingkat keabuan suatu citra dapat ditunjukkan menggunakan histogram [6].

Perataa histogram dapat diperoleh dengan cara menghitung derajat nilai gray sebuah piksel dengan sebuah fungsi transformasi [10]. Persamaan yang digunakan untuk menghitung histogram equalization pada citra dengan skala keabuan seperti pada persamaan 2 .

$h_{i}=\frac{n_{i,}}{n}, \quad i=0,1,2,3$

Dimana $\mathrm{n}_{\mathrm{i}}$ merupakan jumlah pixel yang memiliki derajat keabuan I, dan $\mathrm{n}$ merupakan jumlah seluruh pixel di dalam citra.

\subsection{Filter Gaussion}

Setelah proses ekualisasi histogram kemudian citra telur ayam di lakukan proses filtering dengan Gaussian Filter. Filter Gaussian termasuk dari filter $\mathrm{H}$ dalam bentuk matrik $\mathrm{m}$ x n, yang memiliki nilai sama tiap elemennya. Filter ini bersifat LPF sehingga penjumlahan semua elemen adalah satu [10].

\subsection{Ekstraksi Ciri Statistik Orde Pertama}

Ekstraksi ciri merupakan proses awal yang dilakukan untuk klasifikasi dan interpretasi citra [11]. Proses ekstraksi ini berhubungan dengan kuantisasi karakteristik pada nilai ciri citra yang sesuai. Salah satu ekstraksi yang dapat digunakan yaitu dengan metode statistik. Metode statistik menggunakan perhitungan statistik distribusi derajat keabuan (histogram) dengan mengukur tingkat kekontrasan, granularitas, dan kekasaran suatu daerah dari hubungan ketetanggaan antar piksel di dalam citra. Paradigma statistik ini penggunaannya tidak terbatas, sehingga sesuai untuk tekstur-tekstur alami yang tidak terstruktur dari sub pola dan himpunan aturan (mikrostruktur).

Salah satu ektraksi ciri yaitu ekstraksi ciri orde pertama. Ekstraksi ini merupakan metode pengambilan ciri berdasarkan dari nilai karakteristik histogram. Nilai mean dan standar deviasi dapat dihitung berdasar dari nilai-nilai histogram citra [12]. Pada penelitian ini digunakan nilai mean dan standar deviasi. 


\subsection{Pengujian Keakuratan Klasifikasi}

Pada penelitian ini dilakukan pengujian keakuratan hasil klasifikasi dengan menggunakan precision, recall dan accuracy. Persamaan yang digunakan seperti berikut ini:

$$
\begin{aligned}
& \text { Precision }=\frac{T P}{T P+F P} \\
& \text { Recall }=\frac{T P}{T P+F N} \\
& \text { Accuracy }=\frac{T P+T N}{T P+T N+F P+F N}
\end{aligned}
$$

\section{HASIL DAN PEMBAHASAN}

Proses pengujian dilakukan untuk mengetahui tingkat keberhasilan klasifikasi telur omega-3 dan telur biasa. Skenario pengujian yang dilakukan dengan menggunakan 200 data telur, terdiri dari 100 citra telur omega-3 dan 100 citra telur biasa. Data tersebut kemudian dilakukan pembagian menjadi 140 data training dan 60 data uji.

\subsection{Ekualisasi Histogram}

Pada tahap awal dilakukan praproses yaitu grayscale yang bertujuan untuk mengubah citra RGB menjadi citra keabuan. Hasil praproses pada citra seperti ditunjukkan pada Gambar 4.

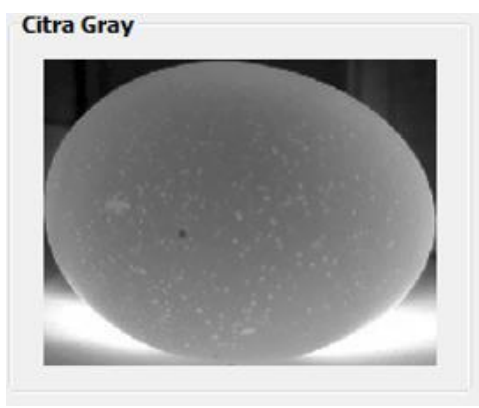

Gambar 4. Proses Grayscale

Tahap selanjutnya melakukan dilakukan proses ekualisasi citra dan gaussian filter. Filter gaussian digunakan untuk mengurangi derau atau noise pada citra yang ditimbulkan pada proses ekualisasi. Gambar 5 merupakan citra hasil ekulisasi dan citra gaussian yang dihasilkan.
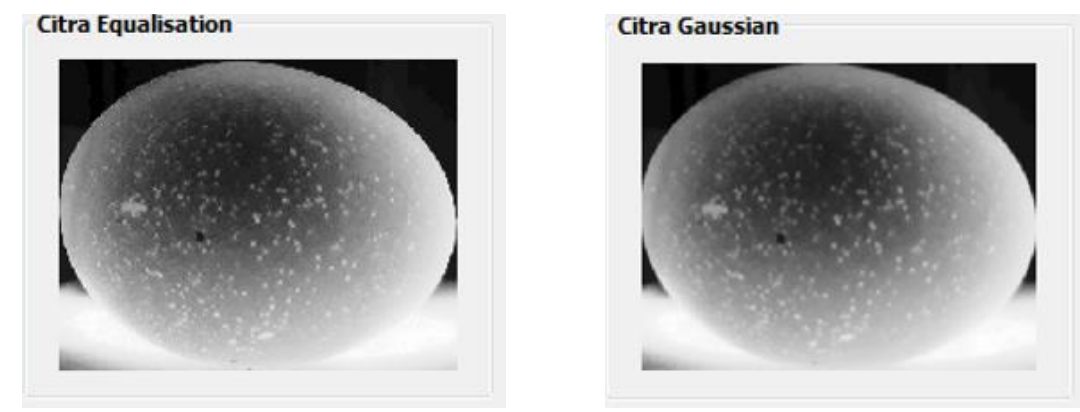

Gambar 5. Proses Ekualisasi Citra Dan Gaussian Filter

Kemudian dari citra hasil gaussian filter dilakukan proses ekualisasi histogram. Gambar 6 menunjukan perbedaan ekualisasi histogram yang dihasilkan pada penelitian ini. 

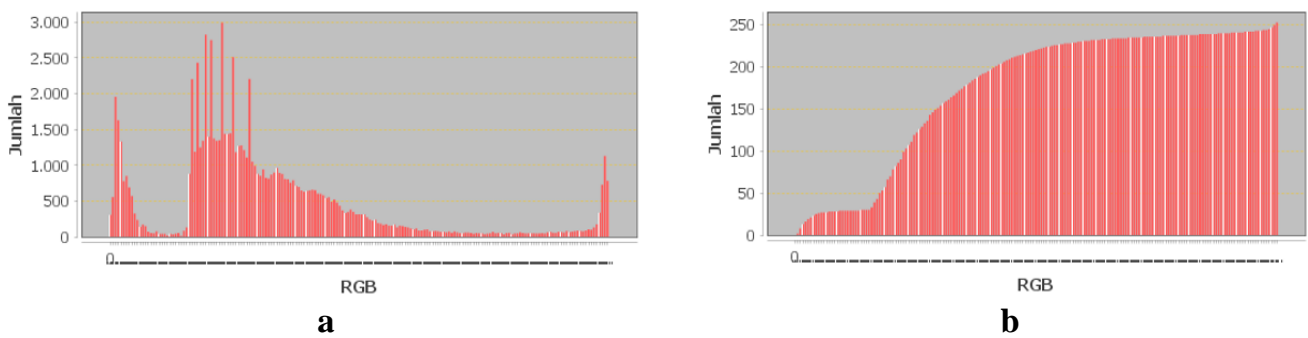

Gambar 6. Ekualisasi Histogram Histogram Citra Awal (a), Histogram Citra Ekualisai (b)

\subsection{Ekstraksi Ciri Statistik Orde Pertama}

Ekstraksi citra menggunakan metode ciri statistik orde pertama. Pada tahapan ekstraksi ciri statistik orde pertama dilakukan perhitungan nilai mean dan standar deviasi. Proses penghitungan ekstraksi ciri dilakukan untuk 140 data training yang sudah disiapkan. Hasil penghitungan ekstraksi citra akan digunakan sebagai batasan untuk menentukan klasifikasi citra telur ayam. Penetapan rentang nilai mean dan standar deviasi yang digunakan untuk menentukan telur ayam omega-3 atau telur ayam biasa ditunjunkan pada Tabel 1.

Tabel 1. Penetapan rentang nilai untuk klasifikasi

\begin{tabular}{ccc}
\hline Jenis Telur & \multicolumn{2}{c}{ Rentang Nilai } \\
\cline { 2 - 3 } Ayam & Mean & Standar Deviasi \\
\hline \multirow{2}{*}{ Omega 3 } & 4.563078953279427 & 157.4091796875 \\
& $>$ Mean $>$ & Standar Deviasi $<$ \\
& 4.560062577525291 & 160.763671875 \\
Biasa & 4.560062577525291 & 160.763671875 \\
& $\geq$ Mean $>$ & $\leq$ Standar Deviasi $<$ \\
& 4.555741940616697 & 167.3466796875 \\
\hline
\end{tabular}

Penetapan rentang nilai pada Tabel 1 digunakan sebagai dasar proses klasifikasi yang dilakukan. Jika pada proses klasifikasi data uji, hasil pembacaaan keluar pada rentang tersebut maka klasifikasi data uji dinyatakan sebagai citra yang tidak dapat diidentifikasi.

Hasil pengujian 60 data uji pada proses klasifikasi diperoleh 51 citra teridentifikasi dengan sempurna dan 9 citra dengan kesalahan pembacaan. Penghitungan hasil pengujian yang dilakukan ditunjukkan pada Tabel 2 .

Tabel 2. Penghitungan hasil pengujian

\begin{tabular}{cccc}
\hline & & \multicolumn{2}{c}{ Nilai sebenarnya } \\
\cline { 2 - 4 } & & TRUE & FALSE \\
\hline Nilai & TRUE & 51 & 7 \\
\cline { 2 - 4 } Prediksi & FALSE & 2 & 0 \\
\hline
\end{tabular}

Berdasarkan pengujian tersebut maka diperoleh precision, recall dan accuracy:
a. Precision
$=51 /(51+7)$
b. Recall $\quad=51 /(51+2)$
$=87.93 \%$
c. Accuracy
$=96.62 \%$
$=(51+0) /(51+7+2+0)$
$=85 \%$

\section{KESIMPULAN}

Berdasarkan hasil pengujian yang dilakukan untuk proses klasifikasi telur omega-3 menggunakan ekstraksi ciri statistik orde pertama didapatkan kesimpulan yaitu

a. Penggunaaan gaussian filter pada proses ekualisasi mampu memperbaiki citra sehingga mempermudah proses ekstraksi ciri.

b. Hasil uji coba proses klasifikasi didapatkan nilai tingkat precision $87,93 \%$, recall $96,22 \%$ dan accuracy $85 \%$. Hasil ini menunjukkan penggunaan ekstraksi ciri statistik orde pertama mampu dijadikan acuan untuk membedakan telur omega-3 dan telur biasa. 


\section{DAFTAR PUSTAKA}

[1] T. Sudaryani, Kualitas Telur. Jakarta: Penebar Swadaya, 2003.

[2] M. Kaewsutas, A. Sarikaphuti, T. Nararatwanchai, P. Sittiprapaporn, and P. Patchanee, "Electroencephalographic study of microalgae DHA omega-3 egg consumption on cognitive function," Journal of Functional Foods, vol. 29, pp. 46-52, Feb. 2017.

[3] S. Arivazhaga, S. Newlin, and K. Rajesh, "External and Internal Defect Detection of Egg using Machine Vision," Journal of Emerging Trends in Computing and Information Sciences, vol. 4, no. 3, 2013.

[4] N. Ningrum, K. Defri, and H. Novi, "Penerapan Ekstraksi Ciri Orde Satu Untuk Klasifikasi Tekstur Motif Batik Pesisir Dengan Algoritma Backpropagasi," Simetris : Jurnal Teknik Mesin, Elektro dan Ilmu Komputer, vol. 8, no. 2, 2017.

[5] Y. Guan et al., "Value of whole-lesion apparent diffusion coefficient (ADC) first-order statistics and texture features in clinical staging of cervical cancers," Clinical Radiology, vol. 72, no. 11, pp. 951958, Nov. 2017.

[6] N. S. P. Kong and H. Ibrahim, "Multiple layers block overlapped histogram equalization for local content emphasis," Computers \& Electrical Engineering, vol. 37, no. 5, pp. 631-643, Sep. 2011.

[7] T. Celik, "Two-dimensional histogram equalization and contrast enhancement," Pattern Recognition, vol. 45, no. 10 , pp. 3810-3824, Oct. 2012.

[8] C. Chen and M. K. Ng, "An image pixel based variational model for histogram equalization," Journal of Visual Communication and Image Representation, vol. 34, pp. 118-134, Jan. 2016.

[9] Y. Wang and Z. Pan, "Image contrast enhancement using adjacent-blocks-based modification for local histogram equalization,” Infrared Physics \& Technology, vol. 86, pp. 59-65, Nov. 2017.

[10] R. Gonzalez and W. Rafael, Digital Image Processing. Prentice-Hall, Inc., United State, America, 2002.

[11] S. Theodoridis and K. Koutroumbas, "Pattern Recognition," in Pattern Recognition (Fourth Edition), Boston: Academic Press, 2009.

[12] Ahmad, Pengolahan Citra Digital dan Teknik Pemrogramannya. Graha Ilmu, Yogyakarta., 2005. 